\title{
Penentuan Desain Optimum Penstock untuk Pembangkit Listrik Tenaga Mikrohidro di Sungai Poreng, Jember
}

\author{
Determination of the Optimum Penstock Design for a Micro-Hydro Power \\ Plant in the Poreng River, Jember
}

\author{
Aldio Dhiva Pratama ${ }^{1}$, Entin Hidayah ${ }^{1 *}$ ), Retno Utami Agung Wiyono ${ }^{1}$ \\ ${ }^{1}$ Jurusan Teknik Sipil, Fakultas Teknik, Universitas Jember, Jember 68121, Indonesia
}

$\begin{array}{ll}\text { Article info: } & \text { Abstrak }\end{array}$

Kata kunci:

Mikro Hidro; Optimasi; Pipa Pesat

Keywords:

Micro Hydro; Optimization; Penstock

Article history:

Received: 03-02-2021

Accepted: 13-06-2021

${ }^{*}$ Koresponden email: entin.teknik@unej.ac.id
Pipa pesat merupakan saluran penghubung antara bak penenang dengan turbin pada rumah pembangkit listrik. Upaya meminimalisir kehilangan energi pada pipa pesat sangat penting untuk mengoptimalkan bangkitan energi listrik. Tujuan penelitian ini adalah melakukan optimasi diameter dan tebal pipa pesat untuk mencari hasil yang paling efisien, yang dikaji dari aspek hidrolika dan biayanya. Metode pemilihan pipa pesat yang optimal dapat ditentukan berdasarkan hubungan secara empiris, antara berbagai formula dari diameter dan tebal pipa pesat yang dinilai terhadap energi yang dihasilkan serta harga pipa pesat itu sendiri. Hasil penelitian menunjukkan bahwa besar diameter pipa berbanding lurus dengan besar energi yang dihasilkan dan berbanding lurus dengan harga pipa pesat tersebut. Berdasarkan perbandingan, didapatkan diameter optimum pipa pesat sebesar 0,45 meter dengan tebal 0,0018 meter yang dihitung menggunakan formula dari Moffat, serta daya bangkitan sebesar $52,16 \mathrm{~kW}$ dan energi yang dihasilkan sebesar $456.914,33 \mathrm{kWh}$ per tahunnya dengan harga pipa IDR 3.610.900 per meter pipa pesat.

\section{Abstract}

Penstock is the connecting channel between the forebay and the turbine in the power house. Minimizing the energy loss in the penstock is very important to optimize the generation of electrical energy. The purpose of this research is to optimize the diameter and thickness of penstock to find the most efficient results, which are examined from the aspects of hydraulics and costs. The optimal method of penstock selection can be determined based on the empirical relationship between the various formulas of the diameter and thickness of the penstock as assessed by the energy produced and the price of the penstock itself. The results showed that the diameter was directly proportional to the amount of energy produced and penstock price. Based on the comparison, the optimum diameter of the penstock is 0,45 meters with a thickness of 0,0018 meters which is calculated using the formula from Moffat, as well as a generation power of $52.16 \mathrm{~kW}$ and energy of $456,914.33 \mathrm{kWh}$ yearly with the price of IDR 3,610,900 per meter penstock pipe.

Kutipan: Pratama, A.D., Hidayah, E., Wiyono, R. U. A., Penentuan Desain Optimum Penstock untuk Pembangkit Listrik Tenaga Mikrohidro di Sungai Poreng, Jember Jurnal Teknik Pengairan.

https://doi.org/10.21776/ub.pengairan.2021.012.01.07 


\section{Pendahuluan}

Pembangkit listrik tenaga mikro hidro (PLTMH) adalah suatu sumber energi alternatif ramah lingkungan, yang dapat dijadikan sumber pembangkit listrik dengan memanfaatkan aliran sungai pada ketinggian tertentu (Morales et al. 2015; Prabowo 2017). Semakin besar kapasitas aliran dan ketinggian aliran, maka akan semakin banyak pula energi listrik yang dapat dihasilkan PLTMH. Namun demikian, kapasitas aliran dan ketinggian aliran yang besar jika tidak didukung oleh desain penstock yang optimal, maka kehilangan energi yang dihasilkan juga akan tinggi (Muhamad and Syuriadi 2016). Pipa pesat atau Penstock, sebagai saluran penghubung antara bak penenang dan turbin, memiliki peran penting dalam menghasilkan energi, karena kekasaran material pipa pesat serta turbulensi air didalam pipa, mengakibatkan kehilangan energi yang yang berpengaruh besar pada pembangkitan energi listrik (Kamis and Amir 2017; Singhal and Kumar 2015).

Dalam menentukan desain diameter pipa pesat yang optimal berbagai metode telah diaplikasikan. Singhal dan Kumar (2015) melakukan penelitian untuk menentukan diameter pipa pesat optimal, dengan melakukan perbandingan pada berbagai persamaan perhitungan diameter pipa pesat, yang diaplikasikan tehadap proyek-proyek pembangunan pembangkit listrik tenaga air di India. Melalui penelitian tersebut, Singhal and Kumar (2015), dapat menemukan persamaan yang paling optimal untuk menghitung diameter pipa pesat, serta dapat menciptakan persamaan mereka sendiri, sesuai dengan standar pembangunan di India. Selain itu, Kravanja (2018), juga melakukan optimasi pada pipa pesat dengan plat pengaku, dengan mengembangkan metode Non-Linear Programming (NLP). Metode NLP tersebut, dilakukan dengan menggunakan optimasi model PIPEWSROPT (PIPE With Stiffener Ring OPTimization) melalui program bantu GAMS (General Algebraic Modeling System), yang kemudian menghasilkan persamaan NLP untuk optimasi pipa pesat bertekanan tinggi yang dapat diaplikasikan untuk pembangunan pembangkit listrik di Slovenia. Rakhmawati, Hadiani, and Solichin (2016), juga melakukan penelitian untuk optimasi pada diameter pipa pesat dengan cara menghitung kehilangan energi dari berbagai diameter pipa pesat, untuk kemudai dibandingakan berdasarkan variasi debitnya terhadap daya bangkitan. Penelitian dari Rakhmawati, Hadiani, and Solichin (2016), memberikan hasil optimasi diameter untuk berbagai variasi debit pada Sungai Kendat, di Kabupaten Boyolali. Yildiz dan Vrugt (2019) mengembangkan model numerik, HYPER, yang dikembangkan menggunakan aplikasi bantu MATLAB. Model numerik ini dapat menghitung energi yang diproduksi, biaya pemeliharan dan operasional, serta keuntungan ekonomik dari suatu pembangkit listrik tenaga air dengan mengoptimasi diameter pipa pesat, tipe turbin, dan konfigurasi sistem turbin.

Fokus dari penelitian ini adalah untuk mengoptimasi diameter dan tebal pipa pesat yang efisien dengan cara membandingkan berbagai macam formula untuk perhitungan diameter dan tebal pipa pesat terhadap output energi yang dihasilkan serta harga pipa pesat itu sendiri. Lokasi penelitian yang digunakan adalah Sungai Poreng pada Sub-DAS Jompo, Jember.

\section{Data dan Metode Penelitian}

\subsection{Persiapan Data.}

Data yang digunakan dari penelitian ini meliputi debit andalan, tinggi jatuh, dan harga pipa. Data debit andalan diperoleh berdasarkan potensi untuk pembangkit listrik dari hasil penelitian oleh Hidayah et al. (2017). Menurut (Hidayah et al. 2017), potensi debit pada Sungai Poreng berada diantara $0,3 \mathrm{~m}^{3} /$ detik hingga $1 \mathrm{~m}^{3} /$ detik serta tinggi jatuh maksimal pada sungai sebesar $15 \mathrm{~m}$. Tinggi jatuh, didapatkan dengan melakukan survei lapangan menggunakan alat Total Station, sehingga diperoleh tinggi jatuh aktual di Sungai Poreng sebesar 8,48 meter. Harga pipa diperoleh dari Analisis Harga Satuan Pekerjaan (AHSP) Bidang Cipta Karya tahun 2019.

\subsection{Metode penelitian}

Metode yang digunakan dalam menentukan diameter dan tebal pipa pesat ini adalah dengan menghitung diameter pipa pesat dengan persamaan (1) hingga (6). Kemudian menghitung kehilangan energi yang terjadi pada pipa pesat dengan persamaan (8) hingga (10). Setelah itu, dapat dihitung bangkitan daya menggunakan persamaan (11) dan energi listrik dengan persamaan (12), yang, selanjutnya digunakan untuk mencari diameter pipa pesat optimal melalui analisis antara hubungan 
diameter pipa pesat dengan bangkitan dayanya. Tahap selanjutnya, adalah menghitung tebal pipa pesat yang kemudian digunakan, bersamaan dengan hasil perhitungan diameter pipa, untuk mencari diameter pipa pesat paling optimal menurut harga pipa pesat itu sendiri. Kemudian, dilakukan analisis lebih lanjut untuk menemukan diameter dan tebal pipa pesat yang paling optimal berdasarkan daya bangkitan dan harga pipanya.

\subsection{Persamaan untuk menghitung diameter dan tebal pipa pesat}

Beberapa peneliti terkemuka telah mencetuskan berbagai macam persamaan untuk mencari desain optimum dari pipa pesat. Persamaan-persamaan tersebut dapat di kategorikan berdasarkan parameter yang digunakan dalam perhitungan diameter pipa pesat. Kategori-kategori tersebut, menurut Mukesh Kumar (2015), antara lain:

a. Berdasarkan Debit (Q)

Warnick (1984) mengembangkan persamaan untuk menghitung diameter optimum dari pipa pesat untuk PLTMH berdasarkan debit desain yang digunakan pada pembangkit. Persamaan tersebut dapat dituliskan sebagai berikut :

$$
\mathrm{D}_{\mathrm{e}}=0,72 \mathrm{Q}^{0,5}
$$

dengan $\mathrm{De}=$ diameter pipa pesat $(\mathrm{m})$ dan $\mathrm{Q}=$ debit aliran $\left(\mathrm{m}^{3} /\right.$ detik $)$

b. Berdasarkan daya terpasang $(\mathrm{P})$ dan tinggi jatuh efektif $\left(\mathrm{H}_{\mathrm{r}}\right)$

Bier (1945), Sarkaria (1979), dan Moffat (1990) masing-masing telah mencetuskaan persamaan untuk menghitung diameter pipa pesat berdasarkan daya terpasang dan tinggi jatuh air efektif. Persamaan tersebut dituliskan seperti pada persamaan (2) hingga (4) dibawah ini

Persamaan Bier (1945)

$$
\mathrm{D}_{\mathrm{e}}=0,176\left(\mathrm{P} / \mathrm{H}_{\mathrm{r}}\right)^{0,466}
$$

Persamaan Sarkaria (1979)

$$
\mathrm{D}_{\mathrm{e}}=0,71 \mathrm{P}^{0,43} / \mathrm{H}_{\mathrm{r}}{ }^{0,65}
$$

Persamaan Moffat (1990)

$$
\mathrm{D}_{\mathrm{e}}=\frac{0,52 \mathrm{P}^{0,43}}{\mathrm{H}_{\mathrm{r}}^{0,60}}
$$

dengan $\mathrm{De}=$ diameter pipa $(\mathrm{m}), \mathrm{P}=$ daya $(\mathrm{kW}), \mathrm{H}_{\mathrm{r}}=$ tinggi jatuh efektif $(\mathrm{m})$

c. Berdasarkan debit (Q) dan tinggi jatuh efektif $\left(\mathrm{H}_{\mathrm{r}}\right)$

Fahlbusch (1987) dan USBR (1949) mengembangkan persamaan untuk menghitung diameter optimum pipa pesat berdasarkan debit pembangkitan dan tinggi jatuh air yang digunakan pada pembangkit. Persamaan tersebut dapat ditulis sebagai berikut

Persamaan USBR (1986)

$$
\mathrm{D}_{\mathrm{e}}=\left(\frac{4 Q}{0,125 * 3,4\left(2 g \mathrm{H}_{\mathrm{r}}\right)^{0,5}}\right)^{0,5}
$$

Persamaan Fahlbusch (1987)

$$
\mathrm{D}_{\mathrm{e}}=1,12 \mathrm{Q}^{0,45} / \mathrm{H}_{\mathrm{r}}^{0,12}
$$

dengan De = diameter pipa (m), Q= debit aliran ( $\mathrm{m}^{3} /$ detik), $\mathrm{H}_{\mathrm{r}}=$ tinggi jatuh efektif $(\mathrm{m})$ 
Selain optimasi pada diameter pipa pesat, dapat pula dilakukan optimasi pada ketebalan pipa pesat guna mendapatkan paling sedikit pada pemasangan pipa pesat. Persamaan yang digunakan untuk perhitungan pipa pesat, menurut USBR (1986), adalah sebagai berikut

$$
\mathrm{T}_{\min }=\frac{D+20}{400}
$$

dengan $\mathrm{T}_{\min }=$ tebal minimum pipa (inchi) dan $\mathrm{D}=$ diameter pipa (inchi)

\subsection{Kehilangan energi pada pipa pesat}

Kehilangan energi pada pipa pesat, menurut Luthfi (2016) dan Ariansyah (2018), ada 3 Persamaan untuk menghitung kehilangan energi tersebut dapat ditulis sebagai berikut:

a. Kehilangan energi akibat bentuk mulut pipa

$$
\mathrm{H}_{\mathrm{e}}=\mathrm{K}_{\mathrm{e}} \frac{v^{2}}{2 g}
$$

dengan $\mathrm{H}_{\mathrm{e}}=$ kehilangan energi akibat bentuk mulut pipa $(\mathrm{m}), \mathrm{K}_{\mathrm{e}}=$ koefisien bentuk mulut pipa, $v=$ kecepatan air $\left(\mathrm{m}^{2} /\right.$ detik $)$, dan $g=$ percepatan gravitasi $\left(9,81 \mathrm{~m}^{2} /\right.$ detik $)$

Nilai $K_{\mathrm{e}}$ dapat dilihat pada Tabel 1.

Tabel 1. Nilai koefisien $\mathrm{K}_{\mathrm{e}}$

\begin{tabular}{llc}
\hline \multicolumn{1}{c}{ Tipe } & Bentuk & Nilai $\mathrm{K}_{\mathrm{e}}$ \\
\hline Runcing & \multicolumn{1}{c}{} & 1,0 \\
\hline Menjorok & \multicolumn{1}{c}{} & 0,8 \\
\hline Ujung Tegas & & 0,5 \\
\hline Sedikit Membulat & & 0,2 \\
\hline & & 0 \\
\hline
\end{tabular}

(Sumber : Ariansyah, 2018)

b. Kehilangan energi akibat gesekan dengan dinding pipa

$$
\mathrm{H}_{\mathrm{f}}=\mathrm{f} \frac{L}{D} \frac{v^{2}}{2 g}
$$


dengan $\mathrm{H}_{\mathrm{f}}=$ kehilangan energi akibat gesekan $(\mathrm{m}), \mathrm{f}=$ koefisien gesekan pada pipa, $\mathrm{L}$ = panjang pipa $(\mathrm{m}), \mathrm{D}=$ diameter pipa $(\mathrm{m}), v=$ kecepatan air $\left(\mathrm{m}^{2} /\right.$ detik), dan $g=$ percepatan gravitasi $\left(9,81 \mathrm{~m}^{2} /\right.$ detik $)$

c. Kehilangan energi akibat belokan

$$
\mathrm{H}_{\mathrm{e}}=\mathrm{K}_{\mathrm{b}} \frac{v^{2}}{2 g}
$$

dengan $\mathrm{H}_{\mathrm{e}}=$ kehilangan energi akibat belokan pada pipa (m), $\mathrm{K}_{\mathrm{b}}=$ nilai koefisien berdasarkan sudut belokan, $v=$ kecepatan air $\left(\mathrm{m}^{2} /\right.$ detik $)$, dan $g=$ percepatan gravitasi $\left(9,81 \mathrm{~m}^{2} /\right.$ detik $)$

Nilai $\mathrm{K}_{\mathrm{b}}$ dapat dilihat pada Tabel 2.

Tabel 2. Nilai koefisien $\mathrm{K}_{\mathrm{b}}$

\begin{tabular}{lccccc}
\hline Sudut Belokan & 20 & 40 & 60 & 80 & 90 \\
\hline Nilai $\mathrm{K}_{\mathrm{b}}$ & 0,05 & 0,14 & 0,36 & 0,74 & 0,98 \\
\hline
\end{tabular}

(Sumber : Ariansyah, 2018)

\subsection{Perhitungan energi listrik}

Pada pembangkit listrik tenaga air, umumnya daya dihasilkan dari perubahan tenaga air dengan ketinggian dan debit tertentu menjadi energi listrik melalui perputaran turbin dan generator. Buku Peganngan Teknik Tenaga Listrik I (Arismunandar 2004) menyebutkan bahwa, daya dari suatu pembangkit listrik tenaga air dapat dihitung menggunakan persamaan oleh Fritz Dietzel (1980) yang dapat ditulis sebagai berikut

$$
\mathrm{P}=\eta_{\mathrm{t}} \cdot \eta_{\mathrm{g}} \cdot \mathrm{g} \cdot \mathrm{Q} \cdot \mathrm{H}_{\mathrm{n}}
$$

dengan $\mathrm{P}=$ daya $(\mathrm{kW}), \eta \mathrm{t}=$ efisiensi turbin, $\eta \mathrm{g}=$ efisiensi generator, $\mathrm{g}=$ percepatan gravitasi $(9,81$ $\mathrm{m} 2 /$ detik), $\mathrm{Q}=$ debit aliran ( $\mathrm{m}^{3} /$ detik), $\mathrm{H}_{\mathrm{n}}=$ tinggi jatuh efektif $(\mathrm{m})$

Selanjutnya, besar energi dapat dihitung dengan persamaan berikut

$$
E=8760 P
$$

dengan $\mathrm{E}=$ energi $(\mathrm{kWh})$ dan $\mathrm{P}=$ daya $(\mathrm{kW})$

\subsection{Kontrol Terhadap Water Hammer}

Di dalam suatu aliran tertutup, seperti pipa pesat, fenomena water hammer akan terjadi jika terjadi penutupan katup secara tiba-tiba, pada waktu pompa pertama kali dinyalakan, atau saat tertutupnya jalur aliran air pada pipa pesat. Oleh karena itu, perhitungan ketebalan dan diameter pipa pesat harus mempertimbangkan terjadinya water hammer. Menurut Santoso dan Priyo (2017), tekanan pipa akinat water hammer dapat dihitung menggunakan rumus berikut :

$$
\mathrm{P}=\rho \cdot v_{0} \cdot \mathrm{C}
$$

dengan $P=$ tekanan $\left(\mathrm{n} / \mathrm{m}^{2}\right), \rho=$ massa jenis air $\left(1000 \mathrm{~kg} / \mathrm{m}^{3}\right), \mathrm{v}_{0}=$ kecepatan air $(\mathrm{m} /$ detik $), C=$ kecepatan perambatan gelombang pada pipa (m/detik) 


\section{Hasil dan Pembahasan}

Untuk keperluan penelitian, digunakan data debit $(\mathrm{Q})=1,077 \mathrm{~m}^{3} /$ detik, panjang pipa $(\mathrm{L})=8,58$ $\mathrm{m}$, kecepatan aliran masuk kedalam pipa $(v)=5,86 \mathrm{~m} /$ detik dan material pipa terbuat dari baja. Jenis turbin yang direncanakan adalah turbin crossflow dengan spesifikasi daya terpasang sebesar $15 \mathrm{~kW}$ dan effisiensi turbin $87 \%$. Selain itu, muka air diasumsikan berada pada bak penenang dengan elevasi $8,06 \mathrm{~m}$ terukur dari muka air pada bak penenang hingga mulut turbin. Mulut pipa dipilih bentuk mulut lonceng karena memiliki nilai kehilangan energi terkecil, yaitu sebesar 0. Belokan pada pipa didesain memiliki sudut $40^{\circ}$ dengan belokan berada dekat dengan mulut pipa dan dekat dengan sambungan antara pipa pesat dengan mulut turbin. Layout rencana untuk perencanaan pipa pesat dapat dilihat pada Gambar 1.

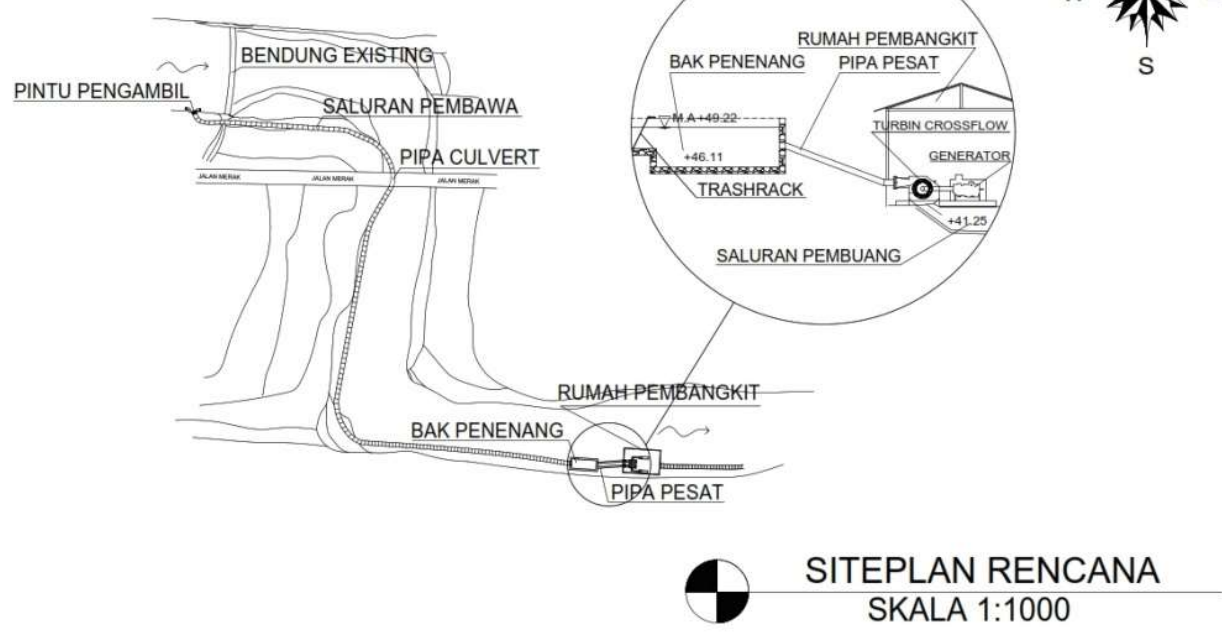

Gambar 1. Layout rencana untuk perencanaan pipa pesat

Berdasarkan data di atas, kemudian dilakukan perhitungan diameter pipa pesat menggunakan persamaan (1) hingga (6). Setelah itu, dapat dihitung kehilangan energi pada pipa melalui persamaan (8) hingga (10), yang kemudian digunakan untuk mencari tinggi jatuh efektif. Data debit dan data tinggi jatuh efektif, selanjutnya dapat digunakan untuk menghitung daya serta energi listrik bangkitan melalui persamaan (11) dan (12), dengan hasil yang disajikan pada Tabel 3.

Tabel 3. Hasil perhitungan diameter pipa pesat dan daya untuk berbagai formula

\begin{tabular}{|c|c|c|c|c|c|c|c|c|}
\hline \multirow{2}{*}{$\begin{array}{l}\text { Persamaan } \\
\text { yang } \\
\text { digunakan }\end{array}$} & \multirow{2}{*}{$\begin{array}{l}\text { Diameter } \\
(\mathrm{m})\end{array}$} & \multirow{2}{*}{$\begin{array}{c}\text { Elevasi M.A } \\
\text { pada bak } \\
\text { penenang } \\
(\mathrm{m})\end{array}$} & \multicolumn{3}{|c|}{ Kehilangan energi (m) } & \multirow{2}{*}{$\begin{array}{l}\mathrm{Hn} \\
(\mathrm{m})\end{array}$} & \multirow{2}{*}{$\begin{array}{l}\text { Daya } \\
(\mathrm{kW})\end{array}$} & \multirow{2}{*}{$\begin{array}{c}\text { Energi } \\
\text { per tahun } \\
(\mathrm{kWh})\end{array}$} \\
\hline & & & Mulut & Gesekan & Belokan & & & \\
\hline Bier & 0,23 & 8,06 & 0 & 4,83 & 0,245 & 2,99 & 25,39 & $222.386,12$ \\
\hline Fahlbusch & 0,89 & 8,06 & 0 & 0,64 & 0,245 & 7,18 & 61,03 & $534.620,01$ \\
\hline Moffat & 0,45 & 8,06 & 0 & 1,68 & 0,245 & 6,13 & 52,16 & $456.914,33$ \\
\hline Sarkaria & 0,56 & 8,06 & 0 & 1,25 & 0,245 & 6,57 & 55,83 & $489.030,56$ \\
\hline USBR & 0,92 & 8,06 & 0 & 0,61 & 0,245 & 7,20 & 61,22 & $536.291,96$ \\
\hline Warnick & 0,75 & 8,06 & 0 & 0,82 & 0,245 & 7,00 & 59,48 & $521.050,21$ \\
\hline
\end{tabular}

Menurut hasil perhitungan, pada tabel 3, dapat dilihat bahwa persamaan Fahlbusch, USBR, dan Warnick merupakan persamaan yang menghasilkan energi listrik bangkitan dengan nilai tinggi, 
sedangkan persamaan Bier, menghasilkan bangkitan energi listrik terkecil. Hasil pada Tabel 3, selanjutnya dianalisa dengan mengambil data diameter pipa, tinggi jatuh efektif, dan daya bangkitan yang kemudian dilakukan perbandingan, menurut persamaannya, seperti pada Gambar 2.

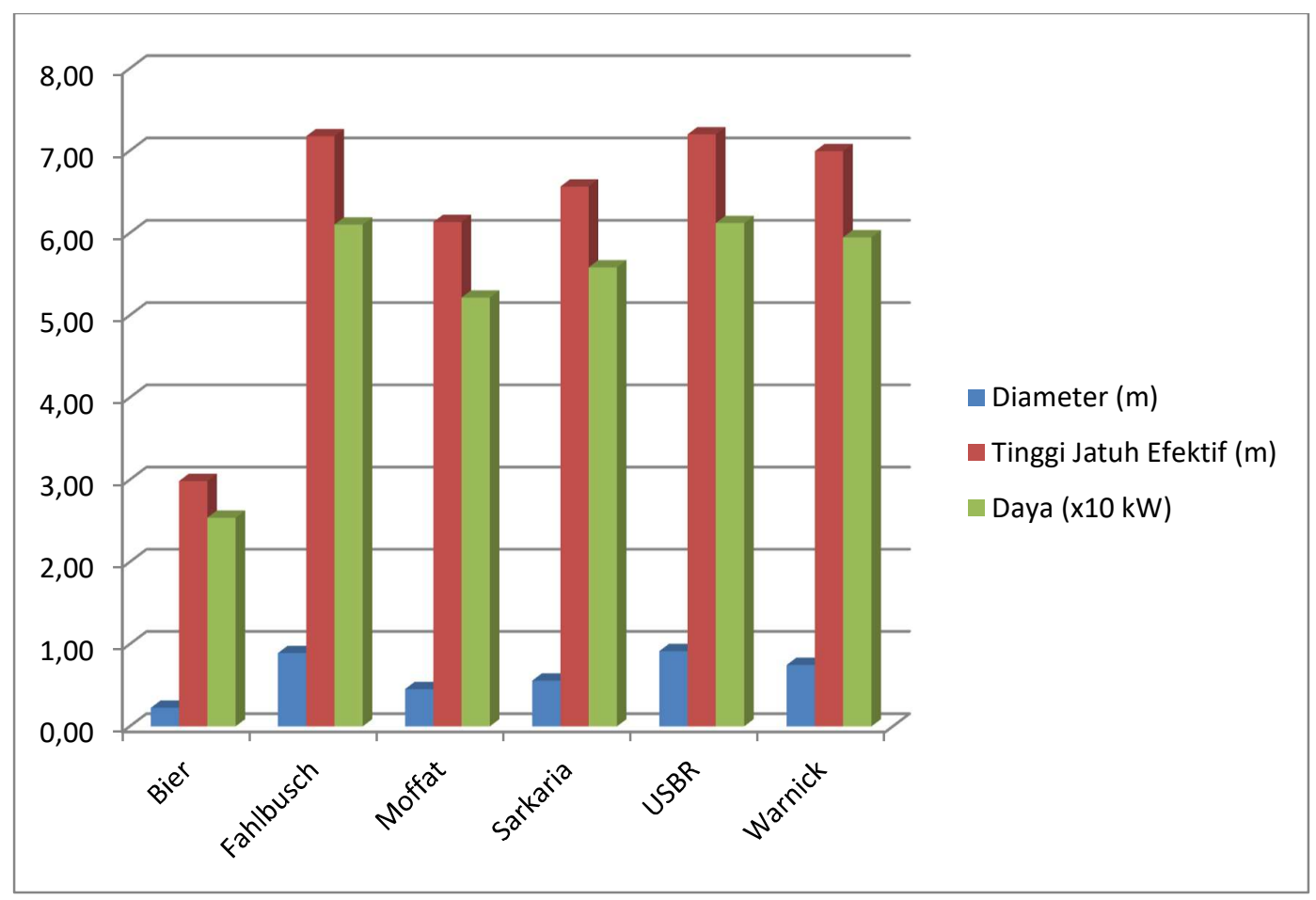

Gambar 2. Perbandingan hasil perhitungan untuk berbagai persamaan

Dapat dilihat dari Gambar 2, bahwa semakin besar diameter pipa pesat, maka semakin besar pula daya yang akan dihasilkan. Hal ini dapat terjadi, karena dengan diameter pipa yang besar, semakin kecil nilai gesekan yang terjadi pada pipa. Dengan demikian, headloss total yang terjadi juga semakin kecil, sehingga didapatkan nilai tinggi jatuh efektif yang maksimum dan output daya yang optimal. Persamaan Bier, menurut data yang ada, merupakan persamaan dengan hasil diameter dan daya yang paling kecil, hal in terjadi karena pada persamaan Bier, kehilangan energi akibat gesekan dengan dinding pipa merupakan yang terbesar, dengan nilai 4,83 m sehingga menghasilkan tinggi jatuh efektif yang kecil serta daya yang kurang optimal. Berbeda dengan Bier, persamaan dari USBR merupakan persamaan dengan diameter dan daya yang paling optimal, dikarenakan tinggi jatuh efektifnya yang besar, sehingga dapat menghasilkan daya yang paling optimal sebesar $61,22 \mathrm{~kW}$.

Selain dari segi daya, perencanaan pipa pesat juga dapat dioptimalkan melalui harga pipa pesat itu sendiri. Untuk mencari paling kecil, diperlukan data diameter serta tebal pipa pesat, data diameter menggunakan diameter-diameter pada tabel 3, sedangkan tebal pipa dapat dihitung menggunakan persamaan (7). Hasil perhitungan tebal pipa, menunjukkan bahwa, antara diameter dan tebal pipa pesat memiliki hubungan yang linier positif. Hubungan antara tebal pipa pesat terhadap diameter pipa pesat dapat dilihat pada Gambar 3. 


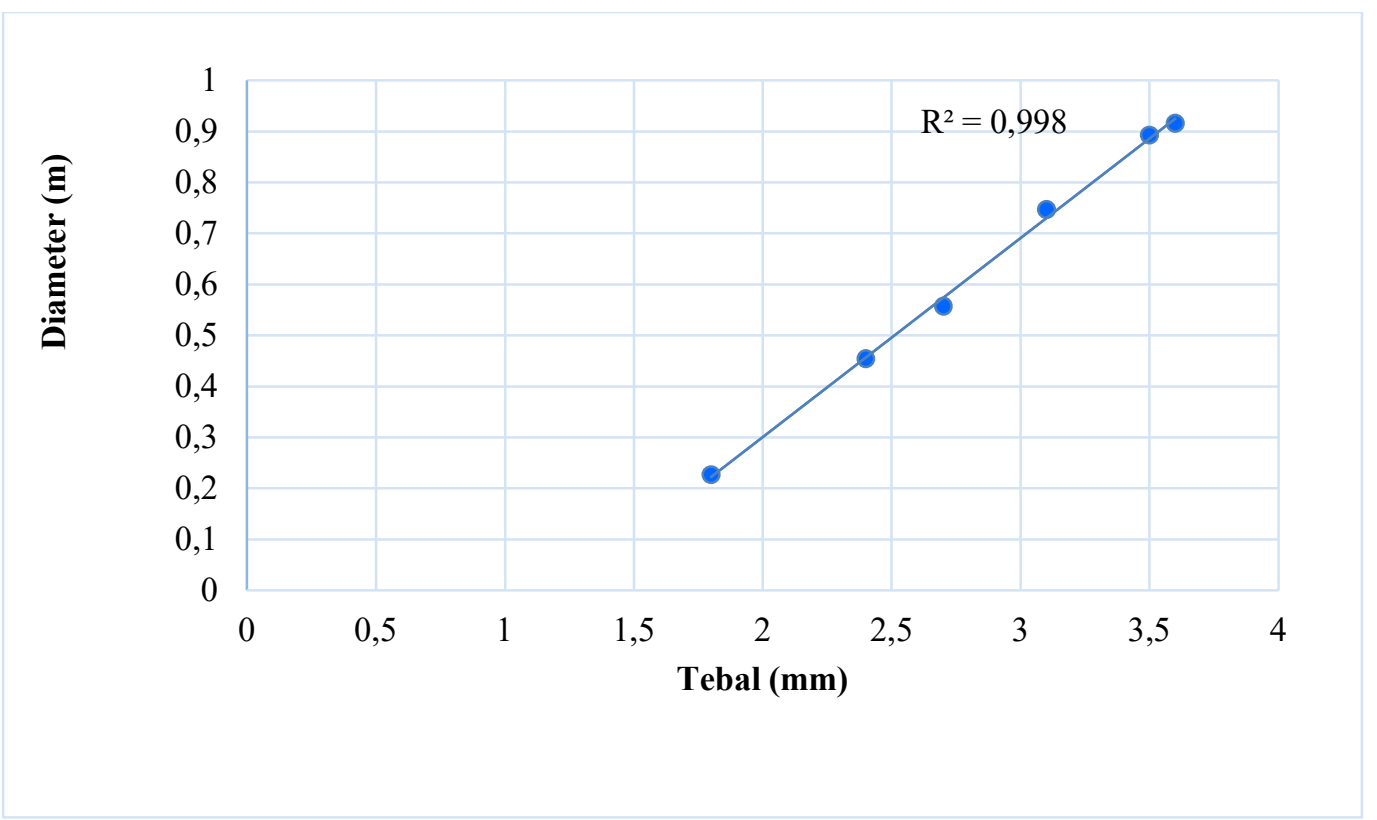

Gambar 3. Hubungan antara tebal pipa pesat terhadap diameter pipa pesat

Selanjutnya, dengan asumsi pipa pesat menggunakan material pipa DCI (Ductile Cast Iron), dengan spesifikasi harga menurut AHSP Cipta Karya Kabupaten Jember 2019, didapatkan hasil harga per meter pipa pesat seperti berikut pada Tabel 4.

Tabel 4. Harga per meter pipa pesat

\begin{tabular}{cccc}
\hline $\begin{array}{c}\text { Diameter } \\
\text { Rencana } \\
(\mathrm{m})\end{array}$ & $\begin{array}{c}\text { Diameter Pakai } \\
(\mathrm{m})\end{array}$ & $\begin{array}{c}\text { Tebal } \\
(\mathrm{m})\end{array}$ & $\begin{array}{c}\text { Harga Per Meter } \\
(\text { IDR })\end{array}$ \\
\hline 0,227 & 0,3 & 0,0031 & 1.027 .300 \\
\hline 0,454 & 0,6 & 0,0018 & 3.610 .900 \\
\hline 0,557 & 0,6 & 0,0027 & 3.610 .900 \\
\hline 0,747 & 0,8 & 0,0024 & 4.885 .200 \\
\hline 0,893 & 1 & 0,0036 & 6.034 .400 \\
\hline 0,916 & 1 & 0,0035 & 6.034 .400 \\
\hline
\end{tabular}

Dari hasil pada Tabel 3 dan Tabel 4 dapat dicari persamaan yang paling optimal, menurut daya dan harganya. Persamaan optimal ini dapat dicari dengan membandingkan daya bangkitan PLTMH dari Tabel 3 dengan harga pipa per meter dari Tabel 4. Perbandingan daya dan harga pipa pesat, dapat dilihat pada Gambar 4.

Dari Gambar 4, dapat dilihat bahwa persamaan paling optimal, jika ditinjau dari daya dan harga pipa per meternya, ada diantara persamaan Moffat, Sarkaria, dan Warnick. Buku Hydropower Engineering (1984) menyatakan, bahwa persamaan Warnick dan Sarkaria ditemukan pada periode waktu sebelum adanya kondisi krisis energi seperti sekarang dan tidak menghitung kehilangan energi pada pipa pesat akibat panjang pipa, maka dari itu persamaan Warnick dianjurkan untuk digunakan dengan sangat hati-hati. Berbeda dengan persamaan Warnick dan Sarkaria, persamaan Moffat telah disesuaikan dengan standar pembangunan modern, sehingga sesuai untuk digunakan pada masa sekarang. Menggunakan persamaan (13), dapat dihitung besarnya water hammer yaitu sebesar $8,2 \times 10^{6} \mathrm{n} / \mathrm{m}^{2}$. Jika dibandingkan dengan tegangan ijin untuk pipa DCI, sebesar $1,4 \times 10^{7} \mathrm{n} / \mathrm{m}^{2}$, maka 
pipa dengan diameter pakai 0,6 meter dan tebal minimum 0,0018 meter masih kuat untuk menahan fenomena water hammer.

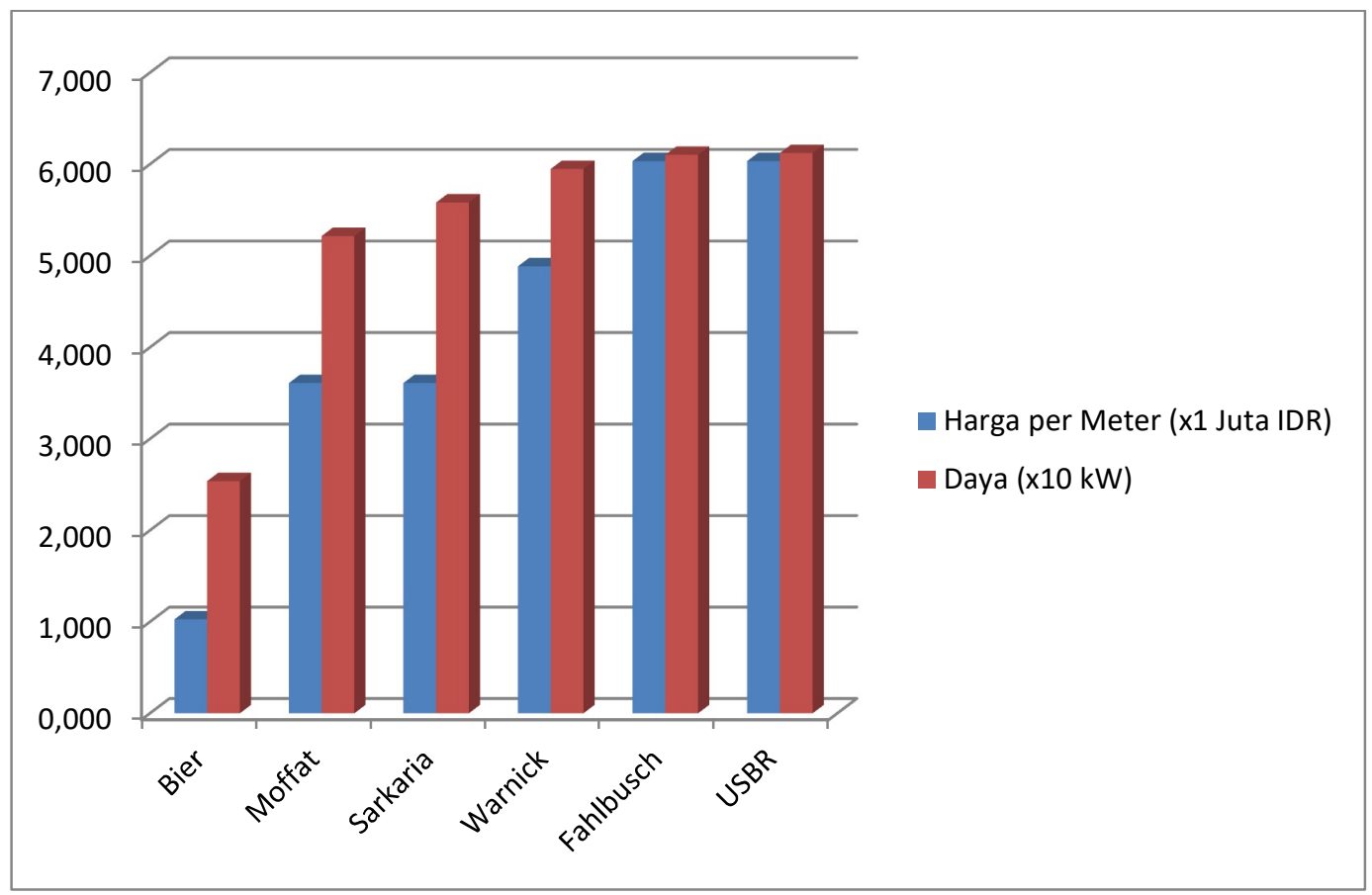

Gambar 4. Perbandingan antara daya dan harga per meter pipa pesat

\section{Kesimpulan}

Berdasarkan hasil analisis, diperoleh diameter pipa pesat optimum pada PLTMH, jika ditinjau dari daya dan pipa pesat, sebesar 0,45 meter dengan diameter pakai 0,6 meter yang dihitung menggunakan persamaan Moffat, serta tebal pipa minimum 0,0018 meter dengan harga IDR 3.610.900 Per meter pipa.

\section{Daftar Pustaka}

Ariansyah, Aida Putri. 2018. "Perencanaan Pembangkit Listrik Tebaga Mikrohidro Pada Bendung Karet Jatimlerek Kecamatan Plandaan Kabupaten Jombang." : 9.

Arismunandar, Artono. 2004. Teknik Tenaga Listrik I. Jakarta: PT. Pradnya Paramita.

Hidayah, Entin, Indarto, Sri Wahyuni, and Propoded Method. 2017. "Proposed Method to

Determine The Potential Location of Hydropowerplant: Application at Rawatamtu

Watershed, East Java." Procedia Engineering 171: 1495-1504.

Kamis, Marlina, and Ruslan Amir. 2017. "Studi Pipa Pesat Pada Pembangkit Listrik Tenaga Mikrohidro (Pltmh).” Jurnal Teknik DINTEK 10(02): 44-50.

Kravanja, Stojan. 2018. "Optimization of a Steel Penstock With Stiffener Rings.” Electronic

Journal of the Faculty of Civil Engineering Osijek-e-GFOS (17): 64-73.

Luthfi, Miftah. 2016. "Perencanaan Pembangkit Listrik Tenaga Mikro Hidro Pada Waduk Sidodadi Glenmore Banyuwangi." 1.

Moffat, Iain, Pavel Novak, and Rangaswani Naryanan. 2017. Taylor \& Farncis Hydraulic Structures. 4th ed. New York: Taylor \& Francis.

Morales, Sergio et al. 2015. "An Overview of Small Hydropower Plants in Colombia: Status,

Potential, Barriers and Perspectives." Renewable and Sustainable Energy Reviews 50: 165057.

Muhamad, Irfan, and Adi Syuriadi. 2016. "Analisis Faktor Head Losses Penstock Terhadap Daya Yang Dihasilkan Di Plta Saguling." POLITEKNOLOGI 15(3): 239-44.

Prabowo, Yusuf Setya. 2017. Perencanaan Pembangkit Listrik Tenaga Mikro Hidro Desa Sutopati 
Pratama, Hidayah, Wiyono : Penentuan Desain Optimum Penstock untuk Pembangkit Listrik Tenaga Mikrohidro

Kecamatan Kajoran Kabupaten Magelang. Surabaya.

Rakhmawati, Tsani, Raden Roro Rintis Hadiani, and Solichin Solichin. 2016. "Optimasi Diameter Pipa Pesat Pada Model Pembangkit Listrik Tenaga Mikrohidro (Pltmh).” Matriks Teknik Sipil 4(3): 759-65. https://matriks.sipil.ft.uns.ac.id/index.php/MaTekSi/article/view/568.

Santoso, Emie, and Agus Priyo. 2017. "Analisa Pengaruh Water Hammer Terhadap Pipe Stress Jalur Pipa Avtur Terminal ISG Tanjung Perak-DPPU Bandara Juanda.” Proceedings Conference on Piping Engineering and its Application 2(1): 51-54.

Singhal, Mukesh Kumar, and Arun Kumar. 2015. "Optimum Design of Penstock for Hydro Projects." International Journal of Energy and Power Engineering 4(4): 216.

USBR. 1986. Welded Steel Penstocks. Engineering Monograph No. 3. Washington: U.S Goverment Printing Office. http://www.usbr.gov/pmts/hydraulics_lab/pubs/EM/EM03.pdf. Warnick. 1984. Hydropower Engineering. New Jersey: Prentice-Hall.Inc.

Yildiz, Veysel, and Jasper A. Vrugt. 2019. "A Toolbox for the Optimal Design of Run-of-River Hydropower Plants." Environmental Modelling and Software 111: 134-52. https://doi.org/10.1016/j.envsoft.2018.08.018. 